\title{
ЗМІНИ ПОКАЗНИКІВ ПЕРЕКИСНОГО ОКИСНЕННЯ ЛІПІДІВ I АНТИОКСИДАНТНОЇ СИСТЕМИ У ПЕЧІНЦІ ЩУРІВ ПРИ ВИКОРИСТАННІ ЛІКАРСЬКОГО ЗАСОБУ «МЕКСИДОЛ" НА ТЛІ ЕКСПЕРИМЕНТАЛЬНОГО ОЖИРІННЯ ТА БРОНХІАЛЬНОЇ АСТМИ
}

\author{
Зміни показників перекисного окиснення ліпідів \\ і антиоксидантної системи у печінці щурів при \\ використанні лікарського засобу «Мексидол» на \\ тлі експериментального ожиріння та бронхіальної \\ астми

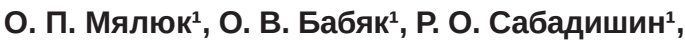 \\ А. П. Данилюк ${ }^{2}$ А. А. Пастернак ${ }^{2}$ \\ КЗВО «Рівненська медична академія» Рівненської \\ обласної ради \\ Обласний науковий ліцей Рівненської обласної ради²
}

Резюме. Проблема профрілактики та лікування бронхіальної астми (БА) в поєднанні з ожирінням може бути вирішення лише на підставі глибокого розуміння біохімічних і фрізіологічних механізмів фрормування двох патологій. Серед біохімічних механізмів, що лежать в основі їх розвитку, особливе місце займають процеси вільнорадикального і перекисного окиснення. Основними органами-мішенями при поєднаній патології БА й ожиріння є легені та печінка. Проте недивлячись на розповсюдження даних захворювань, сьогоднішня наука має досить незначні дані про стан перекисного окиснення ліпідів (ПОЛ) і антиоксидантної системи (AOC) печінки саме при БА й ожирінні, а особливо влив на неї антиоксидантів, що потребує вивчення.

Мета дослідження - визначити показники ПОЛ та AOC у печінці щурів при експериментальній моделі ожиріння і БА та вплив на них мексидолу (етилметилгідроксипіридину сукцинату).

Матеріали і методи. Для дослідження було взято 20 статевозрілих білих нелінійних щурів-самців. Дослідних тварин поділили на 4 групи: інтактні - контрольна група (5 щурів), перша група - група спостереження на 15 добу експерименту без корекції мексидолом (5 щурів), друга група - група спостереження на 26 добу експерименту без корекції мексидолом (5 щурів) і третя група - група спостереження на 26 добу експерименту після корекції мексидолом (5 щурів). Досліджували вміст малонового діальдегіду (МДА), дієнових кон'югатів (ДК), супероксиддисмутази (СОД), активність каталази (КТ) та вміст церулоплазміну (ЦП).

Результати. У першій $і$ другій дослідній групах показники ПОЛ зростали $(p<0,05)$. Зниження активності (с). П. Мялюк та ін., 2021
Changes in lipid peroxidation and antioxidant system parameters in the liver of rats using mexidol in experimental obesity and bronchial asthma

O. P. Mialiuk' ${ }^{1}$ O. V. Babiak ${ }^{1}$, R. O. Sabadyshyn ${ }^{1}$, A. P. Danyliuk ${ }^{2}$, A. A. Pasternak ${ }^{2}$

Municipal Institution of Higher Education "Rivne Medical Academy" Rivne Regional Council ${ }^{1}$

Regional Scientific Lyceum Rivne Regional Council2

e-mail: oksankamp@ukr.net

Summary. The problem of bronchial asthma (BA) prevention and treatment in combination with obesity can be solved only on the basis of a deep understanding of the biochemical and physiological mechanisms of two pathologies formation. Among the biochemical mechanisms underlying their development, the processes of free radical and peroxidation occupy a special place. The lungs and liver are the main target organs in the combination of $B A$ and obesity pathologies. However, despite the prevalence of these diseases, today's science has rather insignificant data on the state of LPO-AOS of the liver specifically in BA and obesity, and especially the effect of antioxidants on it, which requires study.

The aim of the study - to determine the parameters of LPO-AOS in the liver of rats in an experimental model of obesity and BA and the effect of Mexidol on them.

Materials and Methods. The study included 20 white non-linear sexually mature rats. Experimental animals were divided into 4 groups: intact - control group (5 rats), group 1 - observation group on day 15 without Mexidol correction (5 rats), group 2 - observation group on day 26 without Mexidol correction (5 rats) and group 3 - observation group on day 26 after Mexidol correction experiment (5 rats). The content of malondialdehyde, conjugated diene, superoxide dismutase, catalase activity, and ceruloplasmin content were studied.

Results. In experimental groups 1 and 2 the LPO parameters increased $(p<0.05)$. Decrease in the activity of the enzymatic link of AOS, but still including the protective reaction of hepatocytes against LPO products explains the increase in the content of superoxide dismutase and catalase in the experimental group 1, but already in the experimental 
фрерментативної ланки АOC, проте все ж включенням захисної реакції гепатоцитів проти продуктів ПОЛ пояснює зростання у першій дослідній групі вмісту СОД $і$ $K T$, але вже у другій дослідній групі концентрація СОД $і$ КТ знизились на 17 і 10 \% $(p<0,05)$ відповідно, стосовно інтактних тварин. Таке зниження вмісту СОД і КТ на 26 добу експерименту без корекції мексидолом пояснюється виснаженням АОС печінки. Так як і ензими СОД та КТ, вміст ЦП змінювався аналогічно. Третя група дослідних тварин підтвердила антиоксидантну активність у тканині печінки препарату «Мексидол», адже знизились показники як ДК, так і МДА і зросли показники АОС.

Висновки. Дослідження тканини печінки підтвердило ефрективність використання препарату «Мексидол» для регуляції показників ПОЛ і АОС при поєднаній патології БА та ожиріння.

Ключові слова: бронхіальна астма; ожиріння; пОЛ; АОС; мексидол.

\section{ВСТУП}

Добре відомо, що ожиріння і надмірний індекс маси тіла (IMT) істотно підвищують ризик різноманітної супутньої патології. Ожиріння розглядають так само як фрактор ризику розвитку бронхіальної астми (БА), у тому числі причини недостатнього ії контролю, i, ймовірно, може впливати на запалення дихальних шляхів. Однак характер цього взаємозв'язку вимагає уточнення. Існують суперечливі дані про взаємодію цих двох багатофакторних захворювань [1]. Проблема профрілактики та лікування БА в поєднанні з ожирінням може бути наближена до свого вирішення лише на підставі максимально глибокого і повного розуміння біохімічних та фрізіологічних механізмів формування двох патологій. Серед біохімічних механізмів, що лежать в основі їх розвитку, особливе місце займають процеси вільнорадикального і перекисного окиснення. Вважається, що значною мірою ушкодження клітин, тканин, органів при розвитку хвороби викликається за допомогою зміни стану біомембран, ферментів, рецепторного апарату та інших у результаті вільнорадикальних і перекисних процесів. Як і при інших запальних захворюваннях, при БА та ожирінні має місце підвищена продукція активних фрорм кисню клітинами запалення (макрофрагами, еозинофрілами, нейтрофрілами). Оксидативний стрес сприяє активації запалення, збільшення тяжкості перебігу БА, зниження відповіді на лікування глюкокортикоїдами, особливо при загостренні захворювання [2].

Основними органами-мішенями при поєднаній патології БА й ожиріння $є$ легені та печінка [3]. Проте недивлячись на розповсюдження даних захворювань, сьогоднішня наука має досить незначні дані про стан перекисного окиснення ліпідів (ПОЛ) і антиоксидантної системи (AOC) печінки саме при БА й ожирінні, а особливо влив на неї антиоксидантів, що потребує більш детального вивчення. I хоча group 2 their concentration decreased by $17 \%$ and $10 \%$ $(p<0.05)$, respectively, in comparison with intact animals. This decrease in superoxide dismutase and catalase on day 26 of the experiment without correction with Mexidol is explained by depletion of liver AOS. As well as enzymes, the content of ceruloplasmin changed similarly. The third group of animals studied confirmed the antioxidant activity in the liver tissue of Mexidol preparation, because both diene conjugates and malonicdyaldehyde values decreased and AOS values increased.

Conclusions. The study of the liver tissue confirmed the efficacy of the use of Mexidol for the regulation of LPOAOS parameters in the combined pathology of $B A$ and obesity.

Key words: bronchial asthma; obesity; LPO; AOS; Mexidol.

застосування антиоксидантів для профрілактики і лікування бронхіальної астми й ожиріння в умовах експерименту не дає однозначних результатів. Можливо, це пов'язано з неправильною оцінкою місця, ролі й значення кожного з компонентів системи антиоксидантного захисту усього організму в процесі розвитку захворювань. Останнє веде до застосування антиоксидантів у невірно обраних дозах, неправильному поєднанні ліків, часу і шляху введення [4].

Метою дослідження було визначити показники ПОЛ та АОС в печінці щурів при експериментальній моделі аліментарного ожиріння і БА та вплив на них мексидолу (етилметилгідроксипіридину сукцинату).

\section{МАТЕРІАЛИ I МЕТОДИ}

Для дослідження було взято 20 статевозрілих білих нелінійних щурів-самців масою 140-160 г. Експериментальні моделі аліментарного ожиріння та БА відтворювалися у віварії Тернопільського національного медичного університету імені І. Я. Горбачевського МОЗ України. Експериментальну модель аліментарного ожиріння відтворювали шляхом застосування індуктора харчового потягу натрієвої солі глутамінової кислоти у співвідношенні 0,6:100,0 та висококалорійної дієти, яка складається із стандартної їжі (47\%), солодкого концентрованого молока (44 \%), кукурудзяної олії (8 \%) і рослинного крохмалю (1\%). Контроль відтворення аліментарного ожиріння здійснювали шляхом зважування тварин, вимірювання назально-анальної довжини та розрахунку IMT (ділення маси тіла у кілограмах на довжину в метрах у квадраті) [5]. Експериментальну модель БА відтворювали за методом P. Andersson (1980) [6]. Тварин 2 доби підряд сенсибілізували внутрішньочеревним введенням 100 мкл фрізіологічного розчину, що містить 20 мкг овальбуміну і 2 мг гідроксиду алю-
Вісник медичних і біологічних досліджень Bulletin of Medical and Biological Research
4(10),2021 
мінію. На 24; 25 і 26 доби щурів поміщали у камеру і піддавали дії аерозолю - 1\% овальбуміну в фрізіологічному розчині упродовж 20 хв [7]. Дослідних тварин поділили на 4 групи: інтактні - контрольна група (5 щурів), перша дослідна група (IMT>25) - група спостереження на 15 добу експерименту без корекції мексидолом (5 щурів), друга група (IMT>30) - група спостереження на 26 добу експерименту без корекції мексидолом (5 щурів) і третя група (IMT>25) - група спостереження на 26 добу експерименту після корекції мексидолом (5 щурів). Мексидол вводили в лікувальному режимі внутрішньочеревно у дозі 100 мг/кг, яка забезпечує максимальну реалізацію його нейропротекторних, протигіпоксичних та антиоксидантних властивостей [8].

Декапітацію тварин проводили ефрірним наркозом, забирали зразки печінки, яку піддавали гомогенізації із бідистильованою водою у співвідношенні 1:1 3 масою тіла. Центрифугували гомогенат при 3000 об./хв протягом 10 хв, для подальших досліджень відбирався супернатант. Досліди проводили, дотримуючись принципів гуманного поводження 3 тваринами, регламентованих вимогами Європейської конвенції про захист хребетних тварин, що використовуються для дослідних та інших наукових цілей (Страсбург, 1986) з утримання, годівлі та догляду за дослідними тваринами, а також виведення їх з експерименту і подальшої утилізації.

Ми дослідили вміст малонового діальдегіду (МДА) за методом Е. Н. Коробейнікова [9], дієнових кон'югатів (ДК) за методом В. Б. Гаврилова [10], вміст супероксиддисмутази (СОД) за методом R. Fried [11], активність каталази (КТ) за методом B. Holmes, C. Masters [12] та вміст церулоплазміну (ЦП) за методом В. Г. Колб і В. С. Камишнікова [13].

Статистичну обробку отриманих результатів дослідження проводили з використанням загальноприйнятих методів варіаційної статистики за допомогою пакета статистичних програм Excel 2002 та Statistika for Windows (Statsoft Ins, США). Рівень вірогідності визначали за критерієм Стьюдента. Відмінності вважалися достовірними при рівні значимості $p<0,05$.

\section{РЕЗУЛЬТАТИ Й ОБГОВОРЕННЯ}

Зростання показників ПОЛ у печінці щурів вже на 15 добу експерименту свідчить про порушення балансу між швидкістю процесів утворення активних форм кисню й АОС, що сприяє процесу перекисного окиснення і призводить до розпаду ненасичених ліпідів.

У гомогенаті тканини печінки у першій групі дослідних тварин концентрація ДК і МДА зросла на $42 \%(p<0,05)$ і $27 \%(p<0,05)$ відповідно. На 26 добу експерименту без корекції мексидолом вміст ДК збільшився на $133 \%$ ( $p<0,05)$, а вміст МДА - на 61\% (p<0,05). У третій групі дослідних тварин підтверджено антиоксидантну активність у тканині печінки препарату «Мексидол», адже знизились показники як ДК, так і МДА - на $95 \%(p<0,05)$ і на 26 \% (р<0,05) відповідно, стосовно другої групи дослідних тварин (рис. 1).

Антиоксидантна система захисту організму контролює і гальмує усі етапи вільнорадикальних реакцій, починаючи від їх ініціації і закінчуючи утворенням гідроперекисів і МДА. Проте вплив поєднаної патології БА й ожиріння створює дисбаланс системи ПОЛ і АОС у тканинах печінки, що можна простежити у дослідженні.

На 15 добу експерименту в гомогенаті тканини печінки зросла активність СОД на $5 \%(p>0,05)$ стосовно контрольної групи, проте статистично незначимо. Вміст КТ теж зріс на $4 \%(p>0,05)$ відносно контрольної групи тварин, що теж виявилось статистично незначимим. Це пояснюється зниженою активністю ферментативної ланки АОС, проте все ж включенням захисної реакції гепатоцитів проти продуктів ПОЛ. На 26 добу дослідження без корекції мексидолом вміст СОД і КТ знизились на $17 \%$ $(p<0,05)$ і $10 \%(p<0,05)$ відповідно, стосовно інтактних тварин. Таке статистично значиме зниження вмісту СОД і КТ пояснюється виснаженням АОС печінки при поєднаній патології БА й ожиріння. На 26 добу експерименту після корекції мексидолом зросли показники СОД і КТ на $7 \%(p<0,05)$ і на 8 \% (р<0,05) стосовно другої групи щурів (рис. 2),

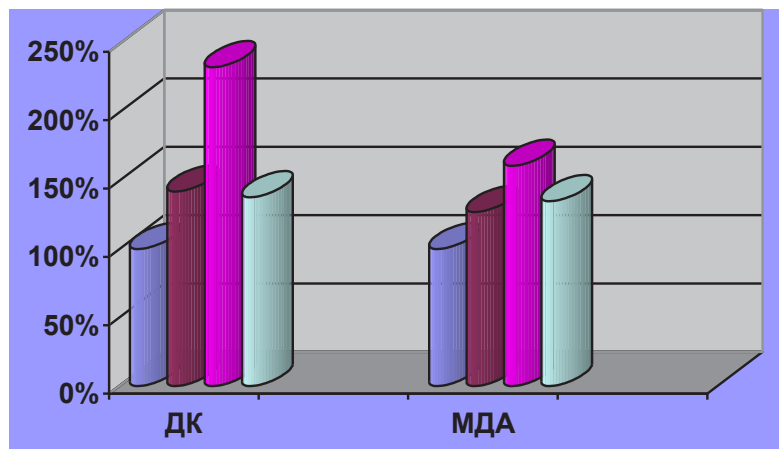

\begin{tabular}{|l|}
\hline Контроль \\
$\square 15$ доба \\
$\square 26$ доба без мексидолу \\
$\square 26$ доба з мексидолом \\
\hline
\end{tabular}

Рис. 1. Вміст дієнових кон'югатів та малонового діальдегіду в печінці щурів при експериментальному ожирінні та бронхіальній астмі до і після корекції мексидолом (\% від контрольної групи). 


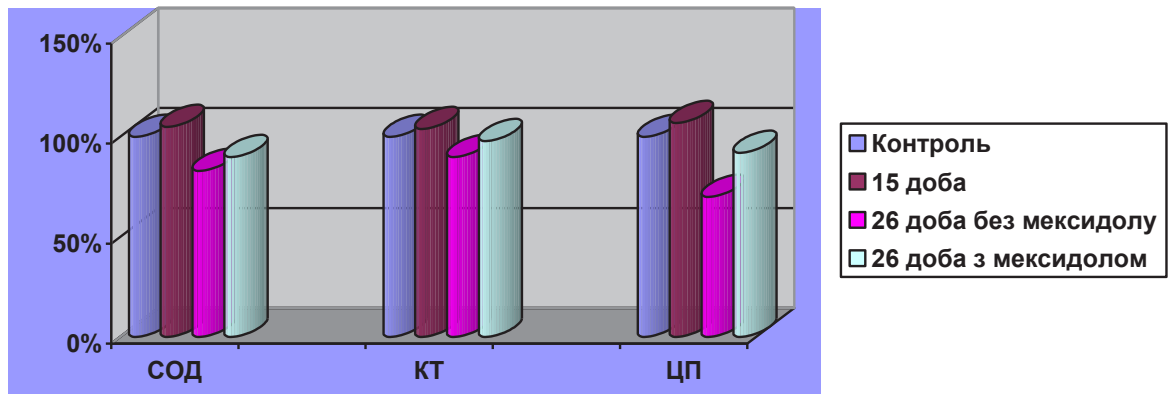

Рис. 2. Вміст супероксиддисмутази, каталази та церулоплазміну в печінці щурів при експериментальному ожирінні та бронхіальній астмі до і після корекції мексидолом (\% від контрольної групи).

що підтверджує високу антиоксидантну активність мексидолу при досліджуваних патологіях.

Найінформативніше неферментативну ланку AOC при поєднаній патології БА й ожиріння визначати концентрацією ЦП у гомогенаті печінки, оскільки печінка є основним місцем синтезу церулоплазміну. Так як і ензими СОД та КТ, вміст ЦП веде себе схоже. На 15 добу експерименту його вміст зріс на $7 \%(p<0,05)$ стосовно контролю, на 26 добу до корекції мексидолом знизився на 30 \% $(p<0,05)$ стосовно контрольної групи. Встановлені зміни вмісту церулоплазміну в гомогенаті печінки тварин при досліджуваних патологіях свідчать про зрушення в системі антиоксидантного захисту, насамперед про гальмування процесу перетворення двовалентного заліза до тривалентного, що сприяє накопиченню $\mathrm{Fe}^{2+}$, в результаті чого активується пе-

\section{СПИСОК ЛІТЕРАТУРИ}

1. Theron A. J. Cysteinyl leukotriene receptor-1 antagonists as modulators of innate immune cell function / A. J. Theron, H. C. Steel, G. R. Tintinger [et al.] // J. Immunol. Res. - 2014. - Vol. 2. - P. 16.

2. Insulin resistance as a predictor of incident asthmalike symptoms in adults / B. H. Thuesen, L. L. Husemoen, L. G. Hersong [et al.] // Clin. Exp. Allergy. - 2009. - Vol. 39, No. 5. - P.700-707.

3. Obesity in asthma: more neutrophilic inflammation as a possible explanation for a reduced treatment response / E. D. Telenga, S. W. Tideman, H. A. Kerstjens [et al.] // Allergy. - 2012. - Vol. 67, No. 8. - P. 1060-1068.

4. Cathaoir K. O. Childhood obesity and the right to health / K. O. Cathaoir // Health Hum. Rights. - 2016. Vol. 18, No. 1. - P. 249-262.

5. Мялюк О. П. Особливості перебігу вільнорадикального й енергозабезпечувального окиснення при експериментальному аліментарному ожирінні : дис. ... к-та біолог. наук : 03.00.04 / Мялюк Оксана Петрівна ; Тернопільський державний медичний університет імені І. Я. Горбачевського. - Тернопіль, 2016. - 142 с.

6. Андерссон П. Антиген-індукована бронхіальна анафрілаксія у активно чутливих морських свинок / П. Андерссон // Алергія. - 1980. - № 35 (1). - С. 65-71. рекисне окиснення ліпідів. На 26 добу після корекції мексидолом вміст ЦП зріс на $22 \%(p<0,05)$ стосовно другої дослідної групи.

\section{ВИСНОВКИ}

При експериментальній БА й ожирінні відбувається зростання прооксидантних процесів на тлі поступової депресії антиоксидантного захисту, що вказує на розвиток оксидативного стресу, який посилює запальні процеси в печінці й сприяє прогресуванню даних патологій, але використання препарату «Мексидол» нейтралізує значною мірою активацію ПОЛ у тканині печінки, стимулюючи її антиоксидантний захист. Дане дослідження є лише початковою ланкою, адже важливим є також вплив мексидолу на інші органи і системи при поєднаній патології БА та ожиріння, що потребує подальшого вивчення.

7. Дослідження показників імунітету на моделі бронхіальної астми у лабораторних тварин (щури) при дії стандартизованого екстракту листя реліктового дерева гінкго дволопатевого / Л. В. Кузнєцова, В. І. Літус, В. Д. Бабаджан [та ін.] // Імунологія та алергологія. 2020. - № 3-4. - C.42-47.

8. Ходаківський О. А. Патогенетичне обґрунтування доцільності використання нових похідних адамантану при експериментальній терапії гострої ішемії головного мозку та міокарда (експериментальне дослідження) : авторефр. дис. ... д. мед. н. : спец. 14.03.05 / О. А. Ходаківський. - Одеса., 2014. - 24 с.

9. Коробейникова Е. Н. Модифрикация определения продуктов перекисного окисления липидов в реакции с тиобарбитуровой кислотой / Е. Н. Коробейникова // Лаб. дело. - 1989. - № 7. - С. 8-9.

10. Гаврилов В. Б. Спектрофоотометрическое определение содержания гидроперекисей липидов в плазме крови / В. Б. Гаврилов, М.И.Мишкорудная // Лабораторная диагностика ишемической болезни сердца. - 1989. - C.170-171.

11. Fried R. Enzymatic and non-enzymatic assay of superoxide ifilii / R. Fried // Biochemie. - 1975. - Vol. 57, No. 5. - P. 657-660. 
12. Holmes R. Epigenetic interconversions of the multiple forms of mouse liver catalase / R. Holmes, C. Masters // FEBS Lett. - 1970. - Vol. 11, No. 1. - P. 45-48.
13. Колб В. Г. Определение активности церулоплазмина в крови / В. Г. Колб, В. С. Камышников // Справочник по клинической химии. - 1982. - С. 290-291.

\section{REFERENCES}

1. Theron AJ, Steel HC, Tintinger GR, Gravett CM, Anderson R, Feldman C. Cysteinyl leukotriene receptor-1 antagonists as modulators of innate immune cell function. $J$ Immunol Res. 2014;2: 16.

2. Thuesen $\mathrm{BH}$, Husemoen LL, Hersong LG, Pisinger $\mathrm{C}$, Linneberg A Insulin resistance as a predictor of incident asthma-like symptoms in adults. Clin Exp Allergy. 2009;39(5): 700-7.

3. Telenga ED, Tideman SW, Kerstjens HA, Hacken $\mathrm{NH}$, Timens W, Postma DS et al. Obesity in asthma: more neutrophilic inflammation as a possible explanation for a reduced treatment response. Allergy. 2012;67(8): 1060-8.

4. Cathaoir KO. Childhood Obesity and the Right to Health. Health Hum Rights. 2016;18(1): 249-62.

5. Mialiuk OP. Peculiarities of free radical and energysupplying oxidation during experimental alimentary obesity. Thesis. Ternopil: Ternopil State Medical University; 2016.

6. Andersson P. [Antigen-induced bronchial anaphylaxis in actively susceptible guinea pigs]. Allerhiia. 1980;35(1): 65-71. Ukrainian.

7. Kuznyeczova LV, Litus VI, Babadzhan VD, Yurkina AV, Nazar OV, Bondarenko TM., Kuznyeczov OG. [Study of immunity indicators in the model of bronchial asthma in laboratory animals (rats) under the action of a standardized extract of the leaves of the relict ginkgo biloba]. Imunolohiia ta alerholohiia. 2020;3(4): 42-7. Ukrainian.

8. Khodakivsky OA. Pathogenetic substantiation of expediency of use of new derivatives of adamantane at experimental therapy of acute ischemia of a brain and a myocardium. Doctor's Extended abstract. Odesa; 2014. Ukrainian.

9. Korobeynikova EN. [Modification of the determination of lipid peroxidation products in the reaction with thiobarbituric acid]. Lab delo.1989;7: 8-9. Russian.

10. Gavrilov VB, Mishkorudnaya MI. Spectrophotometric determination of the content of lipid hydroperoxides in blood plasma [Спектросротометрическое определение содержания гидроперекисей липидов в плазме крови]. Kyiv: Zdorovia; 1989. Russian

11. Fried R. Enzymatic and non-enzymatic assay of superoxide ifilii. Biochemie. 1975;57(5): 657-60.

12. Holmes R. Epigenetic interconversions of the multiple forms of mouse liver catalase. FEBS Lett. 1970;11(1): 45-8.

13. Kolb VG, Kamyshnikov VS. Determination of the activity of ceruloplasmin in the blood. Handbook of Clinical Chemistry [Определение активности церулоплазмина в крови. Справочник по клинической химии]. Minsk: Belarus; 1982. Russian. 